\title{
The Regulation of Payment Cards: The Mexican Experience
}

\author{
JOSÉ L. NEGRÍN * \\ Banco de México
}

\begin{abstract}
We present a review of the regulation of general acceptance payment cards in Mexico. We find that there are distortions that may justify public intervention. The market for payment cards is underdeveloped and the usage of debit cards at POS is restricted. Also, the structure of the interchange fee (IF) may hinder POS deployment and limit debit card usage. Banco de Mexico (BM) has regulatory jurisdiction over the payment systems. BM has introduced transparency in banks' charges and removed restrictions to participation. Regarding IF, the Association of Mexican Banks has reduced it without direct regulation.
\end{abstract}

\section{Introduction}

In this paper, we present a review of the regulation of general acceptance payment cards in Mexico. In order to restrict its scope, this analysis is limited to payment cards issued by commercial banks that conform four party systems; thereby, we leave out both payment cards issued by proprietary networks and retail cards of limited acceptance issued by nonbanks. We study credit and debit cards separately because, to a certain extent, they represent different services; finally, we constrain our analysis to transactions performed at points of sales (POS) with payment cards, excluding ATM transactions, which require a separate review.

In terms of the evolution of the infrastructure and usage of payment cards, we find that despite its recent dynamism, the market for payment cards in Mexico still has limited coverage. We identify a problem with the acquiring side of the market, in particular with POS deployment and with the usage of debit cards at POS.

Regarding the market structure and the organization of the payment card industry we find that there is high concentration in payment cards issuing, as there is in the Mexican banking industry as a whole. We present evidence of market power in credit card issuing and of some barriers to entry and other restrictions to participation. In terms of the role of card associations in Mexico we find that small merchants that accept debit cards have been

* Contact author. Av. 5 de Mayo No.1, 1er Piso, Col. Centro, 06059, Tel.5237-2506, jlnegrin@,banxico.org.mx

Acknowledgements: I thank D. Ocampo for her help, comments and overall support. I also thank A. Escalante, A. Guerra, A. Junco, F. Lopez-Gallo, P. O’Dogherty, R. Prager, J. Quijano and J. Sadka for useful comments. The views expressed in this paper are those of the author and not necessarily those of Banco de México. All remaining errors are my own. 
placed at a strong disadvantage with respect to larger merchants; we also document that the brackets in the interchange fee (IF) schedules were based on merchants' volume of sales rather than line of business, that the schedules had remained constant for several years, and that they were the same for Visa and MasterCard.

Having found evidence of market distortions, public intervention may be justified in order to achieve a more efficient retail payment system. The institutions that have legal authority to intervene in the payments card market are the Federal Competition Commission (CFC) and Banco de México (BM). ${ }^{1}$ The former has jurisdiction over the assessment of non competitive practices in all economic sectors; the latter has authority to regulate payment systems. In this context, BM has adopted several regulatory measures in what could be seen as a more general reform of the retail payment systems, not limited to payment cards. The measures adopted could be grouped as follows: the introduction of transparency in banks' charges; the removal of restrictions to participation and entry; and the coordination with market participants, based on the credible regulatory threat of price regulation provided by the law.

In terms of transparency, the Mexican Central Bank has obliged issuers of cards to let their clients know all fees and commission that they are charging them. ${ }^{2}$ Also, BM must be notified of modifications to such charges in advance. BM makes the fees charged by all banks available through Internet, allowing clients to compare prices.

In terms of preventing restrictions to participation, BM's regulation states that all banks must allow payments of credit card balances through electronic transfers, which permit pro-competitive credit card balance transfer arrangements. ${ }^{3}$ Also, it modifies the honor all cards rule so that merchants decide whether to accept only credit cards, only debit cards, or both.

The most frequent regulatory target in payment cards around the world has been the IF. ${ }^{4}$ In Mexico the IF is not set by MasterCard or Visa but by the Association of Mexican Banks (ABM). The Mexican Central Bank has not issued a regulation for IF in credit or debit card transactions. ${ }^{5}$ However, the ABM has reduced both debit and credit IF schedules, and has introduced several categories of IF that discriminate by type of business, which promotes entry of previously non covered segments of the market. Although this set of regulations is a first step in the direction of a more efficient retail payment system, it seems that many barriers to entry persist.

This paper is structured as follows. In the second section we describe the evolution of payment cards in Mexico. In the third section we present evidence of problems and imbalances in the industry. In fourth section we analyze some elements of market distortions and describe the role of card platforms. In the fifth section we describe the regulatory intervention in the payment cards market. The sixth section includes brief comments on some policy issues.

\footnotetext{
${ }^{1}$ There is also the Commission for the Protection of Financial Services Users (Condusef), which has no regulatory attributions. We describe its functions later.

${ }^{2}$ This regulation also applies to other payment services like electronic transfers and ATM charges.

${ }^{3}$ The regulation allows for payments of any type credit (credit card, automobiles, mortgages, etc.) with checks and electronic transfers issued by other banks.

${ }^{4}$ See Weiner and Wright (2005).

${ }^{5}$ Nevertheless, the interchange fee for electronic transfers was set at zero level by BM regulation.
} 


\section{$2 \quad$ Payment cards situation in México}

All chartered commercial banks in Mexico are allowed to issue general acceptance debit and credit cards. Traditionally, non-banks have not issued general acceptance cards, although there are many non-financial retail card issuers that are not analyzed here. ${ }^{6}$ The acquiring business is fully dominated by banks because they are the only institutions allowed to participate in the switches. All banks participating in four party (open) systems are interconnected and, for all practical purposes, there is only one payment card network, since the terms and conditions for participating in the platforms are the same for all banks, regardless of the card brand. In terms of payment card associations, Visa or MasterCard are the only four party schemes. There is also a proprietary network, American Express.

Transactions with both credit and debit cards at points of sale (POS) are signature based and on-line. In fact all payment card transactions travel along the same infrastructure. There are two interconnected switches. One of them, e-Global, is owned by and serves the two largest banks (Banamex and Bancomer); the other switch, Prosa, serves all the remaining banks and belongs to a group of these banks.

\subsection{Payment card issuing: infrastructure and usage}

From 2002 to 2004 the number of credit cards in Mexico has grown at an average rate of $25 \%$, going from 7.8 to 11.7 million cards. The number of credit card transactions and their corresponding value has increased at a yearly average rate of $8 \%$ and $10 \%$ respectively, over the same period (see Appendix, Table A1).

The number of debit cards in Mexico has increased at an annual average rate of $2 \%$ from 2002 to 2004, going from 33 to 34.4 million cards in the period; it is worth mentioning that the number of debit cards increased importantly at the end of the nineties. The number and value of debit card transactions has grown at a yearly average rate of 8.3\% and 9.7\% respectively, in this period (See Appendix, Table A2).

Credit and debit cards may be used to pay at POS or to withdraw cash at ATMs; most debit transactions in Mexico are performed at ATMs. Transactions at ATMs should be treated differently than those performed at POS because they do not represent purchases. They are withdrawals of cash which in turn is used to perform cash transactions. In the second quarter of 2005 , around $75 \%$ of the total number of credit card transactions were carried out at POS, while only $10 \%$ of the debit card transactions had the same destiny. ${ }^{7}$ This study is based on payment card transactions at POS, excluding operations at ATMs (See Appendix, Tables A3 and A4).

The counterpart of the number of payment cards issued is the number of merchants that accept cards. POS have increased at an average yearly rate of $11.6 \%$ from 2002 to 2004 . The number and value of transactions carried out at POS has increased at an average annual rate of $21 \%$ and $24 \%$, respectively over the same period (See Appendix, Table A4). Despite this rapid expansion, POS deployment in Mexico is still very limited. This phenomenon may not be imputable to banks' behavior, since some merchants decide not to accept cards in order to avoid paying taxes.

\footnotetext{
${ }^{6}$ Retail cards are only accepted at the issuing store. The information on this segment of the market is rather scarce. However, retail cards relevance in financing consumption has grown dramatically in the last 5 years. ${ }^{7}$ In terms of total transactions value, $63 \%$ of credit and $5 \%$ of debit were carried out at POS in the same period.
} 


\subsection{Payment cards as two-sided markets}

The growing literature on payment card networks and two sided markets indicates that merchants (POS) and card holders represent two demands (merchants and cardholders) that must be satisfied simultaneously (Hunt, 2003; and Chang and Evans, 2003). This literature shows that the size of the network (measured by the number of transactions) will be as large as the minimum desired demand among the two sides. Since each side imposes an externality on the other, there seems to be a need for a certain balance, in terms of the number of cards relative to the number of POS in the market, for the network to maximize its value. This is what constitutes network's infrastructure. If such balance exists it gives place to the optimal number (value) of transactions.

It is not clear what the balance between the two sides of the market should be. It is also uncertain the number of transactions per card or per POS that would maximize the network's value. Nevertheless, in this section we use the notion of balance to determine the situation of the debit and credit card systems in Mexico as they constitute two sided markets. Although we lack a formal balance definition, we try to determine if a market is out of balance by analyzing the ratios of cards per POS, number (value) of transactions per card and per POS. We compare the debit and the credit card markets in Mexico, and in turn, these markets with the corresponding systems in a number of countries for which the same type of information is available.

\begin{tabular}{|l|l|l|l|l|l|}
\hline Year & $\begin{array}{l}\text { Number of } \\
\text { credit cards } \\
\text { per POS }\end{array}$ & $\begin{array}{l}\text { Number of } \\
\text { transactions } \\
\text { per card }\end{array}$ & $\begin{array}{l}\text { Value of } \\
\text { transactions } \\
\text { per card } \\
\text { (in USD) }\end{array}$ & $\begin{array}{l}\text { Volume of } \\
\text { transactions } \\
\text { per POS }\end{array}$ & $\begin{array}{l}\text { Value of } \\
\text { transactions } \\
\text { per POS } \\
\text { (in USD) }\end{array}$ \\
\hline 2002 & 60.0 & 20.1 & 997.6 & $1,204.9$ & $59,870.5$ \\
\hline 2003 & 64.4 & 17.9 & 841.4 & $1,153.1$ & $54,159.4$ \\
\hline 2004 & 72.7 & 15.7 & 797.2 & $1,140.4$ & $57,939.3$ \\
\hline
\end{tabular}

Table 1: Credit cards as two-sided markets

Source: Banco de México.

The number of credit cards per POS has increased at a yearly average rate of $10.6 \%$ from 2002 to 2004 (see Table 1); that is, there is an improving coverage of the number of credit cards relative to the existent POS infrastructure. Nevertheless, the number and value of transactions per credit card has decreased at a yearly average rate of $11 \%$ and $10 \%$, respectively. ${ }^{8}$ This means that while banks have issued more credit cards, the recipients of the new cards are not using them as much as the holders of previously issued credit cards did. This may be due to different consumption patterns of the new card holders, perhaps because they have lower average income; alternatively, it may be due to the fact that banks are assigning new credit cards to people that already have other credit cards. ${ }^{9}$ In any case, the increase in cards transactions is not proportional to the increase in the number of cards. Finally, the slight change in the volume and value of credit card transactions per POS over the period of analysis may mean that this market is in a stable situation.

\footnotetext{
${ }^{8}$ These are transactions performed at POS with credit cards. Transactions at ATMs have been excluded.

${ }^{9}$ If this was the case and people that already had cards are receiving new cards, this increases the exposure of the system, since it is equivalent to an expansion of the credit limit.
} 
Regarding debit cards per POS, the ratio does not show a consistent pattern from 2002 to 2004 (see Table 2). ${ }^{10}$ Nevertheless, the number of transactions per card and per POS have diminished consistently over the period. The most interesting fact, however comes from the comparison between debit and credit ratios. There are many more debit cards per POS than credit cards. Nevertheless, the number and value of transactions per POS is much higher for credit than for debit. This evidence seems to imply that there is an imbalance in the use debit cards at POS.

\begin{tabular}{|l|l|l|l|l|l|}
\hline Year & $\begin{array}{l}\text { Number of } \\
\text { credit cards } \\
\text { per POS }\end{array}$ & $\begin{array}{l}\text { Number of } \\
\text { transactions } \\
\text { per card }\end{array}$ & $\begin{array}{l}\text { Value of } \\
\text { transactions } \\
\text { per card } \\
\text { in USD) }\end{array}$ & $\begin{array}{l}\text { Volume of } \\
\text { transactions } \\
\text { per POS }\end{array}$ & $\begin{array}{l}\text { Value of } \\
\text { transactions } \\
\text { per POS } \\
\text { (in USD) }\end{array}$ \\
\hline 2002 & 253.7 & 14.1 & 473.6 & 843.9 & $28,420.5$ \\
\hline 2003 & 219.8 & 12.5 & 399.4 & 807.6 & $25,707.3$ \\
\hline 2004 & 229.1 & 11.0 & 378.9 & 798.5 & $27,541.4$ \\
\hline
\end{tabular}

Table 2: Debit cards as two sided markets, excluding transactions at ATMs

Note: The share of transactions at POS was kept constant at the 2005 level. Source: Banco de México.

\subsection{Relevance of card payments within non-cash transactions in Mexico}

In order to put in context the importance of credit and debit cards in Mexico, we consider the number and value of total non-cash retail payments. ${ }^{11}$ Card transactions have been growing as shown before. However, in 2004 they still only represent $28.4 \%$ and $8.8 \%$ of the number and value of non-cash transactions, respectively.

\begin{tabular}{|l|l|l|l|l|}
\hline & Credit & Debit & $\begin{array}{l}\text { Electronic } \\
\text { Transfers }\end{array}$ & Check \\
\hline Million of transactions & 182.7 & 128.0 & 190.7 & 595.1 \\
\hline$\%$ & 16.7 & 11.7 & 17.4 & 54.3 \\
\hline Value of transactions (billions of USD) & 93.9 & 44.2 & 676.7 & 749.5 \\
\hline$\%$ & 6.0 & 2.8 & 43.3 & 47.9 \\
\hline
\end{tabular}

Table 3: Retail payment structure excluding cash transactions (2004)

Note: Electronic Transfers include Direct Debits. Source: Banco de México.

\footnotetext{
${ }^{10}$ The debit card data in this table excludes transactions performed at ATMs.

${ }^{11}$ In this estimation debit and credit card transactions performed at ATMs have excluded again.
} 


\section{Evidence of payment cards market distortions}

\subsection{Limited access to the payment cards market in Mexico}

In 2004, there were over 45 million payment cards in Mexico. Nevertheless, it is believed that a reduced number of households have access to banking accounts. The new Mexican Family Life Survey (2004), that includes national data up to 2002, shows that only $5.6 \%$ of the individuals surveyed had access to credit cards. Similar numbers for credit card usage result from the National Survey of Households Income and Expenditure (2004). ${ }^{12}$ These figures reflect that commonly, the same individuals hold several cards; hence the total number of cards is not a good indicator of market depth.

The Family Life Survey also indicates that $40 \%$ of the credit card holders are not card users, that is, they hold the credit line as a sort of insurance policy for unexpected shocks to their income. Finally, the survey shows that of those who use their credit cards, $63 \%$ declared that they pay the balance in full at the end of each period. ${ }^{13}$ These numbers reveal several peculiar aspects of the credit card business in Mexico; an important fraction of credit cardholders generate commissions to banks, but not transactions nor interest income. Similarly, of those that generate transactions-related income, a large proportion are beneficiaries of the free financing periods and do not pay interest.

Regarding debit card access, the problem seems less dramatic. Although there is no survey indicator of household access, there are 27 million of accounts associated with debit cards. However, it is fairly common that the same person hold more than one account related to a debit card. ${ }^{14}$ The debit card expansion was based on payroll accounts, which has provided banking access to relatively low income employees. Nevertheless, many payroll account holders only use their debit cards to withdraw their entire paycheck from ATMs.

\subsection{Limited network development and imbalances with respect to other countries}

In order to get a better idea of the development of the Mexican payments card market and of the balance between the two sides of the market, it is relevant to compare the data previously presented with information from other countries. ${ }^{15}$

Table 4 shows that the Mexican credit card market is the least developed of the countries included in the sample. Mexico has the lowest number of cards per person and per member of the labor force. It also has the lowest number of transactions per person and one of the lowest values of transactions to GDP. Despite its limited coverage, the number of credit cards per POS and the number of credit card transactions per POS seem to be comparable to some of the countries included. Consequently, despite its limited depth, there does not seem to be much of an imbalance in the credit card market.

\footnotetext{
12 This survey does not ask about credit card holding but about card usage.

${ }^{13}$ Anecdotal evidence from individual banks show a more balanced distribution of convenience users, but it is not representative of the country as a whole.

${ }^{14}$ A partial indicator of access to debit cards is provided by the Family Life Survey; it indicates that only $6.5 \%$ of the people surveyed had a savings account; although there are other types of accounts that also provide access to debit cards, this number implies limited access.

${ }^{15}$ This kind of data is available only for a few countries. Therefore, the analysis may suffer from sample selection problems.
} 


\begin{tabular}{|l|l|l|l|l|l|l|}
\hline & Canada & Germany & Italy & $\begin{array}{l}\text { United } \\
\text { Kingdom }\end{array}$ & $\begin{array}{l}\text { United } \\
\text { States }\end{array}$ & Mexico \\
\hline Cards per capita & 1.7 & 0.4 & 0.4 & 1.1 & 4.4 & 0.1 \\
\hline Cards per labor force & 3.11 & 0.8 & 0.4 & 2.2 & 8.6 & 0.2 \\
\hline Cards per POS & 105.1 & 65.5 & 31.3 & 77.6 & 359.1 & 64.4 \\
\hline Transactions per capita & 47.5 & 7.1 & 6.4 & 30.7 & 61.9 & 1.1 \\
\hline Transactions per card & 28.7 & 17.9 & 14.6 & 27.3 & 14.2 & 12.4 \\
\hline Transactions per POS & $3,016.6$ & $1,175.7$ & 456.8 & $2,115.3$ & $5,101.7$ & 801.1 \\
\hline $\begin{array}{l}\text { Value of transactions/ } \\
\text { GDP (\%) }\end{array}$ & 13.2 & 1.9 & 2.7 & 10.3 & 15.4 & 1.3 \\
\hline
\end{tabular}

Table 4: Credit card market indicators: international comparison (2003)

Note: Numbers for Canada and the United States correspond to 2002. For Mexico, ATM transactions were estimated and excluded. Sources: Number of cards and transactions in Mexico, Banco de México; Population and Mexican GDP, INEGI; Number of cards, transactions, population and GDP in other countries, BIS 2003; Labor Force, OECD.

In the case of the debit card market, the indicators presented in Table 5 suggest that the Mexican market is less developed than other countries in terms of the number of cards per capita and transactions per capita. However, there are two important imbalances in the market, with respect to other countries. The first is the high number of debit cards per POS (conversely, the limited number of POS given that of debit cards). The second is the reduced number of debit card transactions per POS.

\begin{tabular}{|l|l|l|l|l|l|l|}
\hline & Canada & Germany & Italy & $\begin{array}{l}\text { United } \\
\text { Kingdom }\end{array}$ & $\begin{array}{l}\text { United } \\
\text { States }\end{array}$ & Mexico \\
\hline Cards per capita & 1.2 & 1.1 & 0.5 & 1.0 & 0.9 & 0.3 \\
\hline Cards per labor force & 2.2 & 2.3 & 1.1 & 2.0 & 1.8 & 1.3 \\
\hline Cards per POS & 74.8 & 182.6 & 32.5 & 69.0 & 74.4 & 219.8 \\
\hline Transactions per capita & 76.4 & 20.2 & 10.5 & 56.7 & 54.0 & 1.1 \\
\hline Transactions per card & 65.0 & 18.5 & 23.0 & 56.6 & 59.8 & 3.7 \\
\hline Transactions per POS & $4,857.3$ & $3,369.0$ & 746.3 & $3,905.5$ &, 452.5 & 807.6 \\
\hline $\begin{array}{l}\text { Value of transactions/ } \\
\text { GDP (\%) }\end{array}$ & 9.1 & 5.1 & 4.5 & 11.8 & 6.7 & 0.6 \\
\hline
\end{tabular}

Table 5: Debit card market indicators: international comparison (2003)

Note: Numbers for Canada and the United States correspond to 2002. For Mexico, ATM transactions were estimated and excluded. Sources: Number of cards and transactions in Mexico, Banco de México. Population and Mexican GDP, INEGI. Number of cards, transactions, population and GDP in other countries, BIS 2003. Labor Force, OECD.

Clearly, Mexico is the lowest income country included in tables 4 and 5. Comparisons with countries of similar income levels are harder to perform because of the lack of information. Among the few indicators available, we find that the number of debit cards per person in Brazil and Argentina in 2000 were 0.51 and 0.45 respectively; in Mexico 
there where 0.31 debit cards per person in 2003. Similarly, the number of credit cards per person in Argentina, Brazil and Mexico was 0.27, 0.51 and 0.06, respectively. The number of POS per million inhabitants in Brazil and Argentina were 4,281 and 2,017 for 2001, respectively; for Mexico that number was 1,420 in $2004 .{ }^{16}$ Hence, even if we compare Mexico with countries of similar income level, the payment cards market appears underdeveloped.

Summarizing the information from previous sections, it is clear that despite the recent expansion of card payment markets, access to them is limited and the market is still underdeveloped for international standards. That is particularly true for the number of POS. Also, credit and debit card markets seem to be at different stages of development. The credit card market has a clear problem of depth but there does not seem to be an imbalance between issuing and acquiring sides; the debit market, on the other hand, shows deep imbalances both in terms of the number of cards per POS and of the usage of debit cards at POS.

\section{$4 \quad$ Factors related to payment cards market's lack of development}

Given the limitations and imbalances described above, it is necessary to explore some of the factors that may be affecting payment cards market development. Among them, we present evidence of market concentration in card issuing; although it is known that market concentration does not necessarily mean lack of competition, it is more likely that a highly concentrated market will not be competitive. For credit cards, we also study evidence of market power on the issuing side. Finally, we analyze the role of card associations and IFs and examine how these may have affected market performance. We consider that these factors may be hampering the payment cards market development and may justify financial authorities' intervention.

\subsection{Industry concentration indicators}

Table 6 presents concentration measures in the credit card issuing market from 2000 to 2004 , based on the number of contracts. The fraction of the market concentrated by the two (CR2) has never been less than $70 \%$ while the fraction controlled by the four (CR4) largest firms has always been above $80 \%$. The Herfindahl Hirschman Index (HHI) has remained above the limits accepted by the Mexican Competition Commission to authorize mergers without further investigation. ${ }^{17}$ From 2000 to 2002, the HHI had a positive trend reaching its maximum in 2002. From that year on, the HHI decreased, but its level is still is high.

Table 7 includes information about concentration of the debit card market based on the number of demand deposits accounts. ${ }^{18}$ The total number of issuers has declined; the CR2 index is never less than $46 \%$ and the CR4 index is always greater than $70 \%$ of the market. Again, the HHI seems relatively high.

\footnotetext{
${ }^{16}$ See World Bank (2003).

${ }^{17}$ To authorize a merger without further investigation, the resulting HHI must be less than 2,000 points with a maximum increase of 75 points.

${ }^{18}$ The number of demand deposits' accounts was used as proxy of the total number of debit cards issued since in general demand deposits provide the client with a debit card.
} 


\begin{tabular}{|l|l|l|l|l|l|}
\hline & $\mathbf{2 0 0 0}$ & $\mathbf{2 0 0 1}$ & $\mathbf{2 0 0 2}$ & $\mathbf{2 0 0 3}$ & $\mathbf{2 0 0 4}$ \\
\hline Number of issuers & 11 & 8 & 9 & 12 & 11 \\
\hline CR2 \% & $67 \%$ & $78 \%$ & $73 \%$ & $70 \%$ & $72 \%$ \\
\hline CR4 \% & $84 \%$ & $90 \%$ & $89 \%$ & $88 \%$ & $90 \%$ \\
\hline HHI & 3,253 & 3,587 & 3,641 & 3,217 & 2,924 \\
\hline 1/HHI & 3.1 & 2.8 & 2.7 & 3.1 & 3.4 \\
\hline
\end{tabular}

Table 6: Credit card concentration indicators

Note: Data at December. Source: Calculations were made using data from Comisión Nacional Bancaria y de Valores.

Concentration in the acquiring side of the market is also considerably high. In 2004, CR2 was $57 \%$, while five banks concentrated $93 \%$ of the POS. The HHI for 2004 is above 2000 points. There is no participation of non-banks in the acquiring side and banks have agreed to a scheme by means of which a particular merchant can be acquired only by one bank.19 It is relevant to notice that the same large banks that dominate both the issuing and the acquiring sides. Their position allows them to offer promotions to card users that cannot be matched by smaller issuers, making difficult for the latter to gain market presence. It also makes larger banks less vulnerable in the case of interchange fee reductions.

\begin{tabular}{|l|l|l|l|l|l|}
\hline & $\mathbf{2 0 0 0}$ & $\mathbf{2 0 0 1}$ & $\mathbf{2 0 0 2}$ & $\mathbf{2 0 0 3}$ & $\mathbf{2 0 0 4}$ \\
\hline Number of issuers & 29 & 25 & 25 & 24 & 25 \\
\hline CR2 \% & $45 \%$ & $46 \%$ & $60 \%$ & $51 \%$ & $46 \%$ \\
\hline CR4 \% & $78 \%$ & $78 \%$ & $85 \%$ & $72 \%$ & $72 \%$ \\
\hline HHI & 1,737 & 1,790 & 2,433 & 1,833 & 1,683 \\
\hline 1/HHI & 5.8 & 5.6 & 4.1 & 5.5 & 5.9 \\
\hline
\end{tabular}

Table 7: Debit card concentration indicators

Note: Data at December. Source: Calculations were made using data from Comisión Nacional Bancaria y de Valores.

\subsection{Some pricing indicators for credit cards}

One of the main characteristics of payment cards markets is product differentiation. For instance, each bank offers a variety of credit cards with different features. Another characteristic is the diversity of services provided by payment cards, all of which may have a fee associated. Both product differentiation and service bundling tend to mitigate the intensity of price competition. Even though price comparisons across banks' payment cards are complex given the diversity of product characteristics, it is interesting to analyze whether the prices of the services related to a particular product have changed over time.

\footnotetext{
${ }^{19}$ This constraint seems redundant because merchants are not interested in having more than one acquiring bank. Merchants do not want to duplicate some costs nor divide their transactions so they can achieve lower discount rates.
} 
The idea is that, through time, more competition should translate into lower prices and rates.

We carried out a comparison just for the "Classic" credit card issued by a number of Mexican banks for the years 2001 and 2004. We found that the annual fee, cash disposal commission, minimum payment and interest rate have remained practically constant during this period; only the initial (opening) fee has fallen significantly. This means that, at least for the Classic credit cards, competition does not seem to be affecting the terms and conditions in which cards are provided. It is worth underlining that competition in this market occurs basically through product differentiation; differentiation mechanisms like promotions may be costly for banks but does not reflect directly in prices.

\subsection{Price margin indicators for the credit card market ${ }^{20}$}

A better indicator of the limited price competition existing in the credit card market is provided by the margin of price over costs charged by credit card issuers. A Lerner Index $(\mathrm{LI})^{21}$ may be obtained for all relevant issuers for a particular product, Classic credit cards. In this analysis we assume that the marginal cost can be approximated by the respective cost of funds and that the ordinary interest rate is a good proxy for the credit card price.

The results presented in Table 8 show that all banks' LI are relatively high in the period 1998-2003. The average LI is never less than $60 \%$ and the indicators for all banks present a positive trend during this period. It is also worth noting that the variance of the LIs is low and that it decreases over time. This result implies that all banks have tended to set a similar mark up, regardless of their marginal costs. It is also possible to calculate an LI for the market as a whole by weighting each banks LI by its relative participation in the credit card market. The results, presented in the last row of Table 8, show that LIs for the market increased around 28 percentage points from 1998 to 2003. This evidence suggest that banks hold significant market power in the credit card market.

\begin{tabular}{|l|l|l|l|l|l|l|}
\hline & $\mathbf{1 9 9 8}$ & $\mathbf{1 9 9 9}$ & $\mathbf{2 0 0 0}$ & $\mathbf{2 0 0 1}$ & $\mathbf{2 0 0 2}$ & $\mathbf{2 0 0 3}$ \\
\hline Bank 1 & 0.41 & 0.45 & 0.65 & 0.77 & 0.83 & 0.83 \\
\hline Bank 2 & 0.70 & 0.75 & 0.80 & 0.85 & 0.91 & 0.92 \\
\hline Bank 3 & 0.71 & 0.75 & 0.79 & 0.83 & 0.90 & 0.91 \\
\hline Bank 4 & 0.69 & 0.74 & 0.73 & 0.77 & 0.80 & 0.82 \\
\hline Bank 5 & 0.58 & 0.60 & 0.68 & NA & NA & NA \\
\hline Bank 6 & 0.71 & 0.74 & 0.82 & 0.88 & 0.92 & 0.93 \\
\hline Bank 7 & 0.56 & 0.65 & 0.74 & 0.77 & NA & NA \\
\hline Bank 8 & 0.54 & 0.59 & 0.71 & 0.79 & 0.86 & 0.89 \\
\hline Bank 9 & 0.58 & 0.63 & 0.68 & 0.73 & 0.82 & 0.87 \\
\hline Bank 10 & 0.58 & 0.61 & 0.73 & 0.80 & 0.88 & 0.91 \\
\hline Market & 0.62 & 0.68 & 0.75 & 0.81 & 0.88 & 0.90 \\
\hline
\end{tabular}

Table 8: Lerner indices by bank

Note: Data until October 2003. Market Index was calculated using bank's market share as weights. NA:No Available. Source: Interest rate: Infosel. Cost of funds: Banco de México

\footnotetext{
${ }^{20}$ This section rests heavily on Negrin and O'Dogherty (2004).

${ }^{21} \mathrm{LI}=(\mathrm{P}-\mathrm{MC}) / \mathrm{P}$, where $\mathrm{P}=$ price and $\mathrm{MC}=$ marginal cost.
} 


\subsection{Role of card associations and interchange fees (IF)}

Another factor that could be affecting market development is the role of card associations, in particular, that of IF. The latter has recently been the subject of much controversy both at the academic and regulatory level (Evans and Schmalensee, 2005; and Weiner and Wright, 2005). One of the problems with IF has been that its setting process is not known by the end users or financial authorities. Hence, it has been claimed that it may constitute illegal price fixing and that it may be used as a rent extraction instrument by issuing banks. If this were the case, the IF would represent another obstacle to the development of the payment cards market.

In Mexico, banks themselves, through the Association of Mexican Banks, are in charge of four party systems organization. Card platforms (Visa and MasterCard) have a limited role since they do not perform switching functions in local transactions. Not just that, but as we will explain below, card associations do not set the IF; their main role is the provision of the brand and the switching service for international transactions. In fact, consumers frequently do not identify their cards by the platform's brand, but by the brand of the issuing bank. This is particularly true in the case of cards issued by large banks.

Typically, card associations impose a set of rules that all associated banks have to abide by. ${ }^{22}$ Among them, the most analyzed rules are the honor all cards rule and the no surcharge rule. The former forces merchants to accept all cards that have the associations brand, regardless of the card issuer and of the card type. The latter forbids merchants from charging those who pay with cards higher prices than customers who pay with other means.

In Mexico, the ABM has adopted the same set of rules. However, the no surcharge rule does not have its usual content due to regulatory intervention, as we describe later. In 1993 the Competition Commission reached an agreement with a number of banks, by means of which banks could not forbid in their acquiring contracts that merchants offer discounts for cash payments. ${ }^{23}$ Hence, many small stores and even some large merchants provide discounts for cash payments. Additionally, as we will see later, the honor all cards rule has recently been modified by a regulatory measure imposed by BM.

Another rule usually set by the platforms is the duality rule that prevents banks that issue an associations particular brand of cards from issuing other associations' cards, is not applied in Mexico; in fact, the same banks issue both Visa and MasterCard payment cards. Additionally, card associations often set a rule in less than mature markets by means of which only issuers can become acquirers. This rule is still in place in Mexico and it clearly constitutes a barrier to entry to the acquiring market.

Regarding the IF, as in most countries, in Mexico it flows from acquirer to issuer. Again, card associations do not set the IF; it is determined by the ABM in a neither public nor transparent process. Furthermore, the IF schedule itself is not known by the general public. All acquirer banks are subject to the same schedule of IFs but they are free to set merchant's discount rates. Also, issuers freely establish cardholders' benefits and commissions.

The IF became an issue in 1995, when all banks first interconnected to process card transactions. In this section we present the situation of IF up until June of 2004, when BM

\footnotetext{
${ }^{22}$ See Evans and Schmalensee (1999) for a general description of the rules. See Weiner and Wright (2005) for differences in these rules in a set of countries.

${ }^{23}$ Nevertheless, analyzing recent acquiring contracts of several banks, we found that they still contain a provision for the no surcharge rule.
} 
got involved in retail payment systems. Since then, the ABM has altered the IF schedules in different ways; such changes are presented in section 5.

Concerning transactions carried out at POS, there were three IF schedules, one for credit and two for debit. ${ }^{24}$ The IF schedule for credit cards had a simple average proportional rate of around $2.73 \%$, structured in 5 brackets. The only criteria to assign a merchant to a particular bracket in the IF schedule was the (expected) value of merchant's yearly sales.

Regarding transactions performed with debit cards, there was one IF schedule for transactions performed at small merchants and another for transactions performed at the stores of members of a powerful association of retailers (ANTAD). ${ }^{25}$ The debit nonANTAD IF schedule was proportional and identical to that of credit cards (that is, around $2.73 \%$ on average). The debit ANTAD schedule was a set of fixed fees (not proportional to the amount of the transaction) only applied to the members of ANTAD. The specific bracket of debit-ANTAD IF for a particular merchant was based on the number of yearly transactions performed by that merchant; the simple average level of the ANTAD-debit IF was approximately 0.04 US dollars and the schedule had 10 brackets.

This IF panorama implied several problems. In the first place, non-ANTAD merchants, which are relatively smaller, were placed at a strong disadvantage with respect to larger merchants in debit card transactions strictly because they lacked ANTAD's bargaining power. Small merchants did not only face the discrimination based on the quantity discounts incorporated in the IF structure of fees; they also had to pay the corresponding proportional discount rates while ANTAD members faced a fixed fee discount rate schedule. Consequently, small merchants ended up facing much higher discount rates than larger merchants for debit transactions. This situation surely discouraged some smaller merchants from joining the payment network.

It is important to recall that it is not appropriate for debit transactions to face the same IF schedule as credit operations, since the latter imply higher risks and the issuer incurs in the costs of convenience users free financing period. Therefore, the IF schedule in place up until 2004 may have promoted a higher cost means of payment (credit card) at the expense of a cheaper means (debit card).

Secondly, the brackets on the schedules were based on merchants' volume (or number) of sales rather than line of business. Line of business discrimination appears to be a better proxy for elasticity of demand than volume of sales; therefore, the latter is relatively less efficient. $^{26}$

Thirdly, the IF schedule had remained constant for the last five years though several related costs, like funding and data processing, had gone down very significantly in that period. ${ }^{27}$ This meant that cost considerations were absent from IF setting. The fact that the IF has been so stable reveals that the IF is not set by any economic criteria of efficiency, like the maximization of network's value. Rather, the IF emerges from a bargaining

\footnotetext{
${ }^{24}$ It is interesting to mention that in Mexico the IF is charged in many other payment services, not just in the credit and debit card markets. In fact, some of these markets may not even be two-sided in the way literature has defined them (see Rochet and Tirole, 2004).

${ }^{25}$ Sales at the Association of Self Service and Department Stores (ANTAD) represent around 20\% of total national sales.

${ }^{26}$ However, discrimination by volume within a line of business may achieve a higher efficiency level if merchants are sufficiently heterogeneous within that kind of business.

${ }^{27}$ It is worth pointing out that the credit card industry suffered a dramatic drawback as a result of the tequila crisis. The IF schedule that was set at the time remained fairly constant from 1995 to 1999.
} 
process between banks and between banks and large merchants. Since it is the result of a complex bargaining process, the arrangement becomes difficult to modify.

Fourthly, the level of IFs for credit and non-ANTAD debit was perceived to be high for international standards. ${ }^{28}$ On the other hand, the IF applied to ANTAD debit transactions seemed to be low relative to other countries. This may mean that transactions performed with debit cards at small (non-ANTAD) stores provided transfers to those performed at ANTAD merchants.

As we will see in section 6, this situation has been modified recently by the ABM. A final problem with the IF schedule is that it is set by a committee inside the ABM; hence, the schedule is the same for both Visa and MasterCard platforms and there is no competition between platforms in terms of IF. However, this may not be a major problem because international comparisons of IF between Visa and MasterCard reflect that their schedules are rather similar.

\subsection{Additional distortions: barriers to entry}

There are different types of barriers to entry and participation constraints in the payments card market. In some cases, they are set by regulation, in others by bank practices. Regulators need to identify all entry and participation constraints in order to achieve a competitive system. However, efforts to eliminate these barriers may only have an impact in the long run.

Among the barriers imposed by regulation, we find that only banks may participate in switches. ${ }^{29}$ This eliminates non-banks from participating in four party systems. Hence, non-banks can only issue general acceptance cards through chartered banks.

In terms of the barriers imposed by associations, as we mentioned before, Visa and MasterCard have set up a rule that states that only issuers can become acquirers. That restricts entry to the acquiring market. Card associations also impose a barrier to nonbanks entry; associations only provide their brand to issuers subject to the same type of regulation as commercial banks. This excludes non-banks from issuing cards.

With respect to participation constraints, until recently banks refused to receive electronic transfers originating at other banks to liquidate their clients' credits; this practice forced consumers to always keep an account with the bank where they had their debt. Also, it made balance transfers for credit cards impossible. This practice has recently been eliminated by regulation.

\section{$5 \quad$ Public institutions intervention in the payments card market}

The previous sections pointed out some of the problems and imbalances that affect the functioning of credit and debit card networks in Mexico. In addition to those limitations, there is the widespread perception among consumers that banks' fees and commissions charged are too high and that competition between banks is not intense.

\footnotetext{
${ }^{28}$ International comparisons are to be taken with caution because they are not necessarily valid. Differences between prices may reflect varying competition conditions, but they are also related to the organization of the industry and to the quality of the services offered in each country.

${ }^{29}$ See article 88 of the Law of Credit Institutions. The article does not strictly constrain the use of switches by non-banks, but it has been interpreted that way.
} 
This situation may call for public intervention. However, several questions arise at this point. In the first place, it is not clear who should intervene, the Central Bank or the competition authorities. ${ }^{30}$ On the one hand, Banco de Mexico has a forward looking responsibility related to the design of an efficient payments industry; on the other, the Competition Commission's duty is the assessment and correction of non-competitive practices in all economic activities, including payment systems. To the extent that inefficiencies in payments may arise from non-competitive practices, the law provides both institutions with powers to intervene in this industry. This requires close coordination of actions between regulatory institutions in the payment systems arena. Secondly, the instruments that the authorities may use to achieve their goals have to be defined. That is, authorities may apply direct price regulation or rely on competition policy to achieve their goals. To a great extent the law determines the availability of such instruments. Finally, public intervention in retail payments is an issue under intense debate. Both credit and debit cards are generally accepted to be two-sided markets. Regulatory experience in these markets is still scarce, so there is no clear path for regulators to follow at this point in time.

Besides the Competition Commission and BM, in Mexico there is a Commission for the Protection of Financial Services' Consumers (Condusef). However, this commission has no regulatory powers whatsoever. Its main function is to protect consumers from banks' abusive practices, by providing them with information, free legal advice and by mediating with the banks (Condusef Law Art. 5).

In the following subsections we describe regulatory intervention in card payment markets by both the Competition Commission and the Central Bank.

\subsection{The role of competition authorities in payment cards' regulation}

Competition authorities are in charge of assessing and punishing non-competitive behavior in the economy as a whole, including the provision of retail payment services (Competition Law, Art. 2). In general, the Commission has legal powers to impose competition policy through the suspension of what may be considered a non competitive practice or excessive concentration (Competition Law, Art. 35). However, its role is to assess practices that have already taken place; it does not have the powers nor the intention to design an industry but to correct non competitive actions. At any rate, the Commission has been involved in several cases related to payment cards.

In 1993, the Competition Commission initiated an investigation into credit cards fees in which it observed that charges to merchants were the same for all credit cards and that the interest rates charged to cardholders were very similar for all credit cards issued by large banks. Additionally, the credit card business was much more profitable than other financial business in Mexico and more profitable than the same business in other countries. As a consequence of this investigation, the Commission and several major banks signed an agreement in 1994. The agreement committed the banks to eliminate information exchanges that could facilitate price fixing both in the acquiring and issuing markets. The agreement also modified the no surcharge rule, since it forbade banks to disallow discounts for cash purchases in their contracts with merchants. However, banks were still allowed to forbid surcharges for credit card payments.

\footnotetext{
${ }^{30}$ For instance, in the case of Australia, the Reserve Bank has been in charge (RBA, 2000); in the case of the UK and Spain (OFT, 2004, and Secretaría de Estado de Comercio y Turismo, 1999) and of cross border European transactions (Visa Europe, 2005) competition authorities have been in charge of analyzing these issues.
} 
In 1996, the Commission received a formal complaint from American Express against Visa, claiming that the latter would not permit associated banks to issue American Express cards. This application of the duality rule by card associations is equivalent to exclusivity deals, which are forbidden by the Mexican competition law, when they do not present significant efficiency gains and when the firms involved have market power. Subsequently, Visa informed the Competition Commission that it would not prevent its associated banks from dealing with competing brands. The Commission considered that the issue was solved and ordered Visa to let this resolution be known by its associated banks.

In 1997 the Commission began an investigation when some merchants refused to accept debit cards; the problem was solved by an agreement between banks and ANTAD members $^{31}$ with the set up of the special debit IF schedule for ANTAD merchants' transactions, which has already been described. The investigation was closed in 1999 and did not reach a formal conclusion regarding the anti-competitiveness of a multilaterally set IF. Currently, the competition authority is analyzing a case of non-competitive practices in the acquiring market, but at the time this article was written, no decision had been taken.

As can be seen from the former paragraphs, the Competition Commission has basically eliminated the duality rule and made more flexible the no-surcharge rule. It is unclear how these decisions have affected the development of the payment cards market in Mexico.

\subsection{The role of the central bank in payment card regulation}

BM's law provides it with the authority to regulate the payments industry and to promote the usage of the more efficient payment means. One of the main purposes of BM stated in its law is "...promoting the sound development of the financial system and fostering the proper functioning of payment systems" (Art. 1; see also Art. 24). This law also provides BM with "powers to impose sanctions in order to achieve the fulfillment of its objectives" (Art. 27, 29 and 33).

The Law of Credit Institutions (LIC) states that BM has to evaluate if there are "....reasonable competition conditions regarding fees and commissions on deposits, loans and other services provided by financial entities..." at the request of Condusef or any credit institution (Art. 49). The same Article indicates that BM could start such evaluation on its own initiative, but it must ask for the point of view of the Competition Commission to define the relevant market and to assess effective competition. From this perspective, both BM and the competition authorities could assess competition in the payment systems, which emphasizes the need for coordination on this matter.

In terms of the regulatory instruments that BM has at its disposal, recently the Mexican Congress approved the Law for the Transparency and Financial Services Restructuring (LTOSF); this Law states that BM is "entitled to regulate commissions and IFs charged by financial entities in order to promote the proper functioning of the payment systems" (Art. 4). With this law the Mexican Congress reacted to the continuous complains of consumers about the high level of banks' commissions. While BM's mandate is to seek the proper functioning of all payment systems its concern has always been the surveillance of large value payments because they represent a systemic risk. Retail payments have mostly been left to the market. The LTOSF explicitly provided an opportunity for the Central Bank to intervene in retail payment systems.

\footnotetext{
${ }^{31}$ See note 25 .
} 
Although the LTOSF does not explicitly indicate that BM should authorize modifications to commissions and fees, it signals that "financial entities must inform Banco de México in advance of any modification or new commission" that they intend to charge to the public (Art. 7). This may be interpreted as an implicit fee authorization process.

Additionally, the LTOSF states that Financial Entities incur in "discriminatory practices" when they: (i) Take any action that prevents customers of Financial Entities from performing transactions; (ii) Charge different commissions depending on the issuer (of payment means, like credit and debit cards, checks and fund transfers); and (iii) Take any action to prevent or inhibit their own costumers from using other Financial Entities' infrastructure (Art. 8). This definition of discrimination is closely related to that of noncompetitive practices. Therefore, it seems fairly clear that BM has powers to identify and attempt to eliminate non-competitive practices in the retail payment system.

The law emphasizes price setting as BM's main regulatory tool. ${ }^{32}$ However, regulating banks' commissions and fees is not a simple matter. Besides the typical distortions that price regulations might bring about in any industry (Kahn, 1988) adopting these measures in banking is far more complex.

In the first place, banks provide a wide variety of services which tend to be bundled together. Cross subsidization and indirect pricing are a common practice in this industry. This means that any restriction in the setting of a particular service's price is easily compensated by charging more in another. Hence, the impact that regulating one price could have on the price of other related services is uncertain. Also, the variety of concepts for which banks can charge, makes unfeasible the regulation of all prices.

In the second place, price regulation may not even be justified in Mexico, since the banking industry is by no means a traditional monopoly. There are 29 banks that could provide payment card services; in fact, many of them do so and charge a variety of prices for their respective services.

In the third place, the usual reference mechanisms for price regulation do not seem appropriate in banking services. Consider first setting prices based on costs. The problems that arise with cost regulation in terms of information reporting, and cost minimization incentives for market participants, are well known (Laffont and Tirole, 1993). Not only that, but in particular with respect to the IF, several authors have argued that in two sided markets the IF should not be regulated based only on costs (Evans and Schmalensee, 2005; and Rochet and Tirole, 2004). ${ }^{33}$

An alternative to cost regulation is to set prices based on an international benchmark. The problem there is that direct comparisons of the commissions charged in different countries are not appropriate since they reflects not just different service qualities but the peculiar organization of each country's industry.

Summarizing, the situation of payment cards in Mexico seems to call for public intervention. BM has legal powers to intervene, however, the main regulatory instrument provided by the law is price regulation. This instrument is rather blunt and subject to errors. Nevertheless, price regulation may constitute a credible regulatory threat.

\footnotetext{
${ }^{32}$ In the case of some services, the Law does explicitly provide more powers than price regulation. For instance the LTOSF indicates that BM is entitled to regulate the operations and functioning of clearing houses (Art. 15).

${ }^{33}$ Gans and King (2003) analyze a number of alternative approaches to regulate IF.
} 


\subsection{Banco de Mexico's regulatory approach}

In June of 2004, BM launched a reform process of the retail payment systems in order to encourage the use of the most efficient payment systems and to foster banking competition (Ortiz, 2005). If these goals were to be achieved, they would naturally translate into lower consumer commissions. The regulations that BM has adopted may be grouped as follows: introduction of transparency in banks' charges, removal of restrictions on participation and entry, and coordination with market participants using price regulation as a credible threat. Regarding credit and debit cards, the challenge seems to be the development of the market, in particular of the acquiring side and the promotion of the usage of debit cards at POS.

With respect to the IF, as everywhere else, the limited information about its setting process has raised concerns in Mexico. In this case, the IF scale for debit and for nonANTAD debit transactions seems to be high for international standards, while the opposite seems to be the case for the IF applied to ANTAD debit transactions. Furthermore, it is clearly inappropriate that the IF scale for non-ANTAD debit was the same as the scale for credit. In terms of the IF schedule, discrimination based only on sales volume, does not seem to be efficient. The IF level and structure do not provide incentives to small merchants to participate, which again hinders the development of the acquiring side of the market.

\subsubsection{The measures adopted}

Regarding credit and debit cards, the specific measurements that BM enacted after June of 2004, are the following:

In terms of transparency measures:

(1) Banks must let their clients know all fees and commission that they are charging them (BM, 2004).

(2) In particular, for credit cards, the credit contract must specify commissions and charges (BM, 2004).

(3) Banks must report their commissions and fees as well as any changes in those fees (BM is making the fees charged by all banks available through Internet allowing clients to compare prices) (BM, 2004).

In terms of preventing restrictions on participation:

(4) Regarding credit cards, BM has determined that all banks must allow payments of their clients' credits through electronic transfers; this permits credit card balance transfer arrangements which are pro-competitive (BM, 2005).

(5) The honor all cards rule has been modified. Now merchants may decide to accept only credit, only debit of both types of cards. However, if they accept one type of card, they have to take all issuers cards of that type. This may make debit card acceptance more attractive for merchants (BM, 2005).

$\mathrm{BM}$ has not issued a regulation for IF in credit or debit card transactions. However, the $\mathrm{ABM}$ of its own accord has adopted the following measures:

(1) Regarding credit cards, the ABM reduced the IF in February of 2005 by 43 basis points on average (Ortiz, 2005). Additionally, the ABM has eliminated the highest bracket of IF for credit cards. 
(2) In terms of the IF applied to non-ANTAD debit transactions, the IF has been reduced twice between August 2004 and June 2005. The reduction has been, on average, 134 basis points (Ortiz, 2005). The highest IF bracket has also been eliminated. These changes have made the IF for debit card transactions lower on average than those for credit card transactions. The IF for ANTAD debit transactions has remained the same.

(3) The ABM has introduced several categories of IF to discriminate by type of business, both for credit and non-ANTAD debit. Hence, restaurants, hospitals, travel agencies, etc., are facing more appropriate rates. This promotes efficiency and entry of previously non covered segments of the market.

(4) Since the end of 2003, the ABM has tried to promote card acceptance by means of allowing merchants to add up debit and credit transactions volume in order to achieve a lower IF bracket. This could reduce the IF charged to smaller merchants.

(5) Finally, the $\mathrm{ABM}$ has committed to $\mathrm{BM}$ to perform a thorough analysis in order to find a more efficient way to set the IF (ABM, 2005).

It is relevant to mention that the impact of IF reduction over merchants' discount rate and over card holders' benefits in Mexico is still unclear. In the Australian experience IF reductions did not translate entirely into discount rates, although not enough time has elapsed for the IF reduction to have its complete effect; also, consumers' commissions seem to have increased as a result of a lower IF (RBA, 2004). ${ }^{34}$

It is still too early to observe the pass-through of IF changes to discount rates. However, regarding annual or opening commissions charged to cardholders, the effect has been nil not just because banks may not want to lose clients, but because changes in commissions have to be reported to BM before they are implemented. Even though this regulation is not a formal authorization process, it may discourage banks from increasing commissions.

The reduction in IF may drive out of the market small issuing banks for which the IF is a fundamental income source. This opens up the question of the desirability of small issuers' participation. It may be the case that small card issuers do not reach a costefficient scale of operation, but it could also be the case that the costs faced by card issuers disfavor small issuers disproportionally, in particular, the cost of switches. ${ }^{35}$ Considering that small banks may generate social benefits if they produce competitive pressure, financial authorities must decide whether the disadvantages to small issuers from the reductions in IF should be addressed by regulation.

It is important to mention that the Mexican Ministry of the Treasury is supporting POS deployment through a program to install terminals at POS (terminalization program) funded with tax money. Given that in Mexico banks usually pay for POS deployment, the program may provide a significant subsidy to acquirers. The goal of the program is to install up to 300,000 readers in the next couple of years. The terminalization program, plus the other measures that promote the acquiring business, should result in a more balanced two-sided market and a wider use of debit cards at POS.

\footnotetext{
${ }^{34}$ See also Lopez-Gallo and Negrin (2005) on the expected impact of IF changes over discount rates

${ }^{35}$ As has been mentioned before, there is a switch (Prosa) that carries out small banks' transactions and is owned by several mid size banks. This switch has a pricing scheme that provides quantity discounts. Small banks have complained that the resulting difference in the fees paid by small and larger issuers is too great.
} 


\section{Final comments and some policy issues}

The Mexican payment card industry presents serious problems and imbalances. Among them, the market is not deep, and in particular the deployment of POS is limited given the number of cards that have been issued. Also, the usage of debit cards at POS is very low. In terms of the organization of the payment card industry, both issuing and acquiring markets are concentrated and there is some evidence of market power.

Regarding the IF, it is not only set in a non-transparent manner, but its structure may have hindered POS deployment and debit card usage; additionally, its structure has severely disfavored small merchants. Consequently, it does not promote the usage of the most efficient payment means nor the expansion of the network. Along the same lines, the mechanism for setting the IF schedules is only based on the bargaining power of the parties involved. There do not seem to be any efficiency considerations nor network growth criteria in the IF determination process. There is also no evidence that the IF plays the balancing role between acquiring and issuing sides that the literature on this area has studied. In fact, the agreements between banks and large merchants to set the IF schedule, established so that cards are accepted at such stores, seem to have distorted the market.

We believe that this situation points at the need for public intervention. Moreover, regulatory intervention in this market is not new as shown by the no surcharge and duality rules, which were altered by the Competition Commission's involvement. Nevertheless, intervention is not a simple matter. The organization of this market is complex, and regulators have limited information about it. Further, is not even clear that previous intervention has had a positive impact on the market's development.

In this context, BM is committed to achieve an efficient retail payment industry. In order to do so, BM has followed two lines of action. It has adopted regulations that theoretically cannot worsen the market's performance. This is the case of the transparency measures adopted and the removal of barriers to entry and participation. In areas where there is more uncertainty, like the IF, BM has acted cautiously, leaving decisions in the hands of market participants. However, BM has let them know that it is expecting for such decisions to work toward improving market efficiency; if that were not to be the case, BM could use more direct regulations.

$\mathrm{BM}$ regulatory approach has resulted in a more transparent and open system. In term of IF, the new scheme implies lower fees for debit than for credit transactions, and less discrimination against small merchants. It is interesting to notice that in all the countries where there has been some form of public intervention, the IF has gone down (Weiner and Wright, 2005). However, reducing the IF is appropriate only if there is evidence of potential social gains and efficiency improvements from such reduction. In the case of Mexico, reduction in IF - in particular for debit - seems to be the remedy for the network's imbalances. Even though price regulation is allowed by law, BM has not used it yet. There are still many pending issues both in removing barriers to competition and in achieving a more efficient IF system. However, the industry seems to be moving in the right direction.

There are a number of problems that BM still has to consider. In the first place, given the high level of acquiring market concentration, BM has to analyze to what extent the IF reductions have been passed through to merchant service fees. If the impact over discount rates is limited, then the IF reduction only becomes a rent redistribution mechanism from issuers to acquirers. Therefore, it is necessary to gather information to evaluate such transmission. 
In the second place, the reductions in IF hit smaller issuers harder than larger issuers. As long as the IF is set in a manner that improves market efficiency, smaller issuers' problems should be a second order consideration. However, this could affect competition in the issuing market in the long run. In the third place, reviews of the IF have to be performed frequently, given that the cost and market demand conditions are changing continuously. Finally, as in Australia, it is necessary to review that the reduction in IF in four party system promoted by BM, is not providing an unfair advantage to proprietary networks.

\section{$7 \quad$ References}

Asociación de Bancos de México (2005)

http://www.abm.org.mx/quienes/com medios.htm

Banco de Mexico (2005) Circular 5/2005.

http://www.banxico.org.mx/dDisposiciones/Disposiciones2019/5-2005.htm

Banco de Mexico (2004) Circular 13/2004.

http://www.banxico.org.mx/dDisposiciones/Disposiciones2019/13-2004.html .

Chang, H. and D. Evans (2003) "The Economics of Multi-sided Platform Markets," Antitrust Insights, NERA Economic Consulting, July/August, 1-5.

Evans, D. and R. Schmalensee (2005) "The Economics of Interchange Fees and Their Regulation: An Overview," presented at the Conference of Interchange Fees in Credit and Debit Card Industries, Kansas City Federal Reserve Bank, Santa Fe New Mexico, May 46.

Evans, D. and R. Schmalensee (1999) Paying with Plastic: The Digital Revolution in Buying and Borrowing. MIT Press: Cambridge, MA.

Gans, J. and S. King (2003) "Approaches to Regulating Interchange Fees in Payments Systems," Review of Network Economics, 2: 125-145.

Hunt, R. (2003), "An Introduction to the Economics of Payment Card Networks," Review of Network Economics, 4: 80-96.

Kahn, A. (1988) The Economics of Regulation: Principles and Institutions. MIT Press: Cambridge, MA.

Laffont, J.J. and J. Tirole (1993) A Theory of Incentives in Procurement and Regulation. MIT Press: Cambridge, MA. 
López-Gallo, F. and J. L. Negrín (2005) "Effects of Interchange Fee Changes on Merchant Service Fees and Cardholders' Benefits", mimeo, Banco de México.

Mexican Government (1993) Ley de Banco de Mexico.

Mexican Government (1993) Ley Federal de Competencia Económica.

Mexican Government (2000) Ley de Protección y Defensa al Usuario de Servicios Financieros.

Mexican Government (2004) Ley de Instituciones de Crédito.

Mexican Government (2004) Ley para la Transparencia y Ordenamiento de los Servicios Financieros.

Negrin, J. L. and P. O’Dogherty (2004) "Estructura y Competencia en el Mercado de Tarjetas de Crédito," en Competencia Económica en México, compiled by Comisión Federal de Competencia, Editorial Porrúa: México.

Office of Fair Trade (2003) UK Payment Systems, May.

Ortiz G. (2005) "Remarks on Interchange Fees: Central Bank Perspectives and Options", Speech presented at the Conference of Interchange Fees in Credit and Debit Card Industries, Kansas City Federal Reserve Bank, Santa Fe New Mexico, May 4-6.

Reserve Bank of Australia (2004) "Merchant Service Fees for Credit Cards," Bulletin, July.

Reserve Bank of Australia and Australian Competition and Consumer Commission (2000) Debit and Credit Card Schemes in Australia a Study of Interchange Fees and Access.

Rochet, J. and J. Tirole (2004) "Defining Two-Sided Markets," mimeo, IDEI and GREMAQ, Toulouse.

Secretaría de Estado de Comercio y Turismo (1999) "Acuerdo Sobre Tarjetas de Pago," España, 12 de mayo.

Visa Europe (2005) Interchange fees, http://www.visaeu.com/acceptingvisa/interchange.html

Weiner S. and J. Wright (2005) "Interchange Fees in Various Countries: Developments and Determinants," Review of Network Economics, 4, 290 - 323

\section{$8 \quad$ Appendix}

\section{Credit Cards}

\section{Growth Rates}




\begin{tabular}{|l|l|l|l|l|l|l|}
\hline Year & $\begin{array}{l}\text { Number } \\
\text { of credit } \\
\text { cards } \\
\text { (millions) }\end{array}$ & $\begin{array}{l}\text { Number of } \\
\text { transactions } \\
\text { (millions) }\end{array}$ & $\begin{array}{l}\text { Value of } \\
\text { transactions } \\
\text { (in USD) }\end{array}$ & $\begin{array}{l}\text { Number } \\
\text { of credit } \\
\text { cards }\end{array}$ & $\begin{array}{l}\text { Number of } \\
\text { transactions }\end{array}$ & $\begin{array}{l}\text { Value of } \\
\text { transactions }\end{array}$ \\
\hline 2002 & 7.8 & 212.8 & 12.3 & -- & -- & -- \\
\hline 2003 & 9.4 & 228.8 & 12.5 & $21 \%$ & $8 \%$ & $2 \%$ \\
\hline 2004 & 11.7 & 248.4 & 14.7 & $24 \%$ & $9 \%$ & $18 \%$ \\
\hline
\end{tabular}

Table A1: Credit cards evolution

Source: Banco de México.

\begin{tabular}{|l|l|l|l|l|l|l|}
\hline \multicolumn{2}{|l|}{ Debit Cards } & \multicolumn{3}{l|}{ Growth Rates } \\
\hline Year & $\begin{array}{l}\text { Number } \\
\text { of debit } \\
\text { cards } \\
\text { (millions) }\end{array}$ & $\begin{array}{l}\text { Number of } \\
\text { transactions } \\
\text { (millions) }\end{array}$ & $\begin{array}{l}\text { Value of } \\
\text { transactions } \\
\text { (in USD) }\end{array}$ & $\begin{array}{l}\text { Number } \\
\text { of debit } \\
\text { cards }\end{array}$ & $\begin{array}{l}\text { Number of } \\
\text { transactions }\end{array}$ & $\begin{array}{l}\text { Value of } \\
\text { transactions }\end{array}$ \\
\hline 2002 & 33.0 & $1,061.3$ & 76.9 & -- & -- & -- \\
\hline 2003 & 32.1 & $1,141.1$ & 78.2 & $-3 \%$ & $8 \%$ & $2 \%$ \\
\hline 2004 & 34.4 & $1,238.4$ & 91.9 & $7 \%$ & $9 \%$ & $18 \%$ \\
\hline
\end{tabular}

Table A2: Debit cards evolution

Source: Banco de México.

\begin{tabular}{|l|l|l|l|l|l|l|}
\hline \multicolumn{2}{|l|}{ Credit Cards } & \multicolumn{3}{l|}{ Growth Rates } \\
\hline Year & $\begin{array}{l}\text { Number } \\
\text { of credit } \\
\text { cards } \\
\text { (millions) }\end{array}$ & $\begin{array}{l}\text { Number of } \\
\text { transactions } \\
\text { (millions) }\end{array}$ & $\begin{array}{l}\text { Value of } \\
\text { transactions } \\
\text { (in USD) }\end{array}$ & $\begin{array}{l}\text { Number } \\
\text { of credit } \\
\text { cards }\end{array}$ & $\begin{array}{l}\text { Number of } \\
\text { transactions }\end{array}$ & $\begin{array}{l}\text { Value of } \\
\text { transactions }\end{array}$ \\
\hline 2002 & 7.8 & 156.6 & 7.8 & -- & -- & -- \\
\hline 2003 & 9.4 & 168.4 & 7.9 & $21 \%$ & $8 \%$ & $2 \%$ \\
\hline 2004 & 11.7 & 182.8 & 9.3 & $24 \%$ & $9 \%$ & $18 \%$ \\
\hline
\end{tabular}

Table A3: Credit card evolution excluding transactions carried out at ATM's

Note: The share of transactions at POS was kept constant at the 2005 level. Source: Banco de México.

\begin{tabular}{|l|l|l|l|l|l|l|}
\hline \multicolumn{2}{|l|}{ Debit Cards } & \multicolumn{3}{l|}{ Growth Rates } \\
\hline Year & $\begin{array}{l}\text { Number } \\
\text { of debit } \\
\text { cards } \\
\text { (millions) }\end{array}$ & $\begin{array}{l}\text { Number of } \\
\text { transactions } \\
\text { (millions) }\end{array}$ & $\begin{array}{l}\text { Value of } \\
\text { transactions } \\
\text { (in USD) }\end{array}$ & $\begin{array}{l}\text { Number } \\
\text { of debit } \\
\text { cards }\end{array}$ & $\begin{array}{l}\text { Number of } \\
\text { transactions }\end{array}$ & $\begin{array}{l}\text { Value of } \\
\text { transactions }\end{array}$ \\
\hline 2002 & 33.0 & 109.7 & 3.7 & -- & -- & -- \\
\hline 2003 & 32.1 & 117.9 & 3.8 & $-3 \%$ & $8 \%$ & $2 \%$ \\
\hline 2004 & 34.4 & 128.0 & 4.4 & $7 \%$ & $9 \%$ & $18 \%$ \\
\hline
\end{tabular}

Table A4: Debit card evolution excluding transactions carried out at ATM's 
Note: The share of transactions at POS was kept constant at the 2005 level. Source: Banco de México.

\begin{tabular}{|l|l|l|l|l|l|l|}
\hline \multicolumn{2}{|l|}{ POS } \\
\hline Year & $\begin{array}{l}\text { Number } \\
\text { of POS }\end{array}$ & $\begin{array}{l}\text { Number of } \\
\text { transactions } \\
\text { (millions) }\end{array}$ & $\begin{array}{l}\text { Value of } \\
\text { transactions } \\
\text { (in USD) }\end{array}$ & $\begin{array}{l}\text { Number } \\
\text { of POS }\end{array}$ & $\begin{array}{l}\text { Number of } \\
\text { transactions }\end{array}$ & $\begin{array}{l}\text { Value of } \\
\text { transactions }\end{array}$ \\
\hline 2002 & 129,971 & 281.3 & 18.9 & -- & -- & -- \\
\hline 2003 & 146,029 & 335.0 & 21.9 & $12 \%$ & $19 \%$ & $16 \%$ \\
\hline 2004 & 160,289 & 397.0 & 27.8 & $10 \%$ & $19 \%$ & $27 \%$ \\
\hline
\end{tabular}

Table A5: POS evolution

Source: Banco de México. 